This is an Accepted Manuscript of an article published by Taylor \& Francis in Atlantic Studies in 2012, available online: http://dx.doi.org/10.1080/14788810.2012.636991 It was part funded by the AHRC (Grant Ref. AH/I027290/1)

\title{
Rethinking the fall of the planter class
}

Christer Petley

University of Southampton

Abstract: This edition of Atlantic Studies began life as a one-day conference held at Chawton House Library in Hampshire, England, funded by the University of Southampton. The conference aimed, like this volume, to bring together scholars currently working on the history of the British West-Indian planter class in the eighteenth and nineteenth centuries and to discuss how, when, and why the fortunes of the planters went into decline. As this introduction notes, the difficulties faced by the planter class in the British West Indies from the 1780s onwards were an early episode in a wider drama of decline for New World plantation economies. The American historian Lowell Ragatz published the first detailed historical account of their fall. His work helped to inform the influential arguments of Eric Williams, which were later challenged by Seymour Drescher. Recent research has begun to offer fresh perspectives on the debate about the decline of the planters, and this collection brings together articles taking a variety of new approaches to the topic, encompassing economic, political, cultural and social history.

Keywords: planters; slavery; Caribbean; abolitionism; decline theory Email: c.petley@soton.ac.uk 
The fall of the British-Caribbean planter class was an important part of what Philip Curtin has termed "the rise and fall of the plantation complex", the broad outlines of which are well known. ${ }^{1}$ The rise entailed the development between the sixteenth and eighteenth century of New World sugar plantations as the engines of an Atlantic economy, worked by enslaved laborers imported from Africa, transforming societies on all sides of the Atlantic. From the end of the eighteenth century this complex and profitable system of slavery and plantation agriculture came under new forms of pressure. Abolitionists in Europe and in the Americas campaigned successfully against it, first for the end to the transatlantic slave trade and then for the ending of slavery itself. Enslaved people, who had always found ways to challenge this Atlantic slave system, adopted new forms of resistance in the understanding that they were no longer the only opponents of the planter class. Other groups, including missionaries and free people of color in the colonies, worked to undermine and reform aspects of slave societies. And governments on either side of the Atlantic were unable to ignore the tide of discontented criticism that rose against slavery; one by one they were persuaded or cajoled into passing reforms that moved towards its end. These factors precipitated the end of slave holding and the fall of the New World plantation complex. By the close of the nineteenth century, the institution of slavery had disappeared throughout the Americas, helping to seal the economic fate of the planter class across the region. Zones of plantation agriculture remained, and they still exist, but by the twentieth century these were no longer the most economically productive parts of the Americas. Their heyday had been at the height of the Atlantic slave system, during the eighteenth century.

When and where we pinpoint the beginning of the declension of the New World plantation complex is open to debate, particularly given the propensity for plantations 
and the institution of slavery to expand and thrive on new frontiers throughout the nineteenth century. However, the first serious challenges to an important segment of the New World planter class came at the end of the eighteenth century. This period saw the rise in the 1780s of a British campaign to reform the labor systems of tropical colonies in the British Caribbean, beginning with demands for the closure of the transatlantic slave trade. This was followed by the Haitian Revolution, which began in 1791 and saw enslaved people overthrow the slave system in the French colony of St. Domingue. Afterwards, slaveholding planters everywhere had new causes for concern. Abolitionism and antislavery resistance by enslaved people helped to challenge, undermine and defeat regimes of slavery. During the nineteenth century, slaveholders in different parts of the Americas succumbed or bowed to pressure to reform or end their institution. $^{2}$

$<$ INSERT MAP (0 - Intro Map) here or nearby> [Caption for Map:] The Caribbean, c. 1830

The British-Caribbean planter class was the first group of planters in the Atlantic world to come under sustained political pressure from abolitionist opponents. This diverse group was at once British and Caribbean. Many lived on or near their plantations but identified themselves as British subjects; increasing numbers lived in the British Isles, far from the sources of their wealth, keeping in touch with affairs on their West-Indian properties via correspondence with local managers. They were therefore a truly transatlantic group. Wealthier than their North American counterparts in the thirteen mainland colonies and with a strong political voice at the heart of imperial politics in London, the British-Caribbean planters appeared to be a secure and 
successful fixture of the mid-eighteenth-century British-Atlantic system of trade and empire. In spite of their wealth and influence, however, other Britons tended to view planters in a negative light, perceiving them to be rough, ready, exotic, and outlandish (Figure 1). They were often portrayed as petty despots or as nouveau-riche upstarts, reputations that mattered little before the rise of organized abolitionist pressure but that later provided a basis for criticisms aimed at reforming the brutal and lucrative Atlantic slave system over which they presided.

$<$ INSERT FIGURE 1 (0 - Intro Fig1) here or nearby> [Caption for Fig. 1:] Figure 1: William Blake, "A Surinam Planter in his Morning Dress" (engraving based on a sketch by John Stedman), in John Stedman, Narrative of a Five Year's Expedition against the Revolted Negroes of Surinam, vol. 2, facing 56. Courtesy of the Hartley Library Special Collections, University of Southampton.

Although it depicts a planter in the Dutch colony of Suriname, Blake's image captures many eighteenthcentury stereotypes associated with slaveholders in tropical America, including the British Caribbean. Stedman's accompanying text described the planter as "like a petty monarch, as capricious as he is despotic." The picture shows him "with a pipe in his mouth, which almost everywhere accompanies him, and receiving a glass of Madeira wine and water from a female quadroon slave, to refresh him during his walk." (Stedman, Narrative, 56, 58).

The period of the American Revolution presented British-Caribbean planters with new challenges, and they struggled to respond effectively to the rise and success of abolitionism in the decade that followed. From the end of the 1780s, the planters' already precarious public image rapidly declined as increasing numbers of metropolitan commentators highlighted the barbarities inherent in West Indian slave societies (Figure 
2). The era of the French Revolution further destabilized the planters' world, raising the spectre of democratic challenges to the status quo and throwing the arena of Atlantic commerce into a state of unpredictable disarray. By 1807, abolitionists had succeeded in outlawing the British transatlantic slave trade, and in 1823 the gradual ending of slavery itself became their main objective. Ten years later, and under renewed pressure from radical antislavery activists, the imperial government passed a law ending slavery in the British empire, which eventually came into full effect in 1838 . Within a period of about fifty years, therefore, plantation owners and slaveholders in the British Caribbean had seen their slave system questioned, undermined, reformed, and then abolished. Economic challenges accompanied the planters' political defeats, and the equalization of the sugar duties in 1846 deepened their plight, further exposing the produce of the British-Caribbean to withering competition from the better and cheaper sugars grown by planters in Cuba and Brazil, planters who still maintained systems of slavery. In these ways, a powerful slaveholding group whose activities had been at the heart of the British imperial economy were, by the middle of the nineteenth century, diminished and marginalized. ${ }^{3}$

$<$ INSERT FIGURE 2 ( 0 - Intro Fig2) here or nearby>

[Caption for Fig. 2:] Figure 2: James Gillray, "Barbarities in the West Indies" (hand-colored etching, published 23 April 1791) @ National Portrait Gallery, London (NPG D12417). Gillray's grotesque cartoon provides an image of slaveholders as cruel, sadistic and morally corrupt, an image that had become common currency in the metropole by the 1790 s and that helped to ensure that political campaigns against the planters were popular and successful. 
The experiences of British planters were, of course, different to those of other groups of slaveholders, but the pattern of political defeat and economic decline was not unique to this group. For example, the affluent cotton and rice planters of the US South suffered a military defeat in the Civil War, followed by the abolition of slavery and economic difficulties. Brazilian and Cuban planters also faced straightened economic circumstances when abolitionist pressure forced the gradual abolition of slavery upon them. Moreover, planters and abolitionists in other regions were keenly aware of the important precedent set by slave emancipation in the British Caribbean, which became a touchstone in their debates. ${ }^{4}$

\section{I}

The dramatic rise of slavery and plantation agriculture, followed by the dissolution of slavery and economic difficulties for planters, could imply a sort of natural rhythm in the lifespan of slave production. As Seymour Drescher has suggested, scholars might be tempted "to look for a natural history of the institution in a sequence of youth, maturity, and senility." Some have taken the view that the fall of the plantation complex in the Caribbean was part of the cycle of sugar growing, whereby initial crop yields gave way to exhausted soils and diminished returns. Slavery too can be presented as a system that "had within itself the seeds of its own destruction," bringing with it the inevitability of slave resistance and a disinclination towards technological innovation. ${ }^{6}$ Moreover, as Barry Higman notes, the idea that sugar and the associated rise of slavery "entailed the 'original sin' of West Indian history" has resonated strongly with scholars. ${ }^{7}$ Such perspectives relate closely to late-eighteenth-century interpretations, including Adam Smith's assumptions about the efficiency of free over enslaved labours and the 
Christian-abolitionist belief that the sin of slaveholding entailed degenerate and corrupted societies which would, inevitably, suffer a fall.

Nowhere is the idea of an inherently flawed socio-economic system more clearly on display than in Lowell Ragatz's study, The Fall of the Planter Class in the British Caribbean, first published in 1928. Ragatz advanced the argument that the sugar islands "had been overtaken by economic vicissitudes decades before the slightest obstruction to the free importation of new field hands was raised or the faintest popular demand for emancipation was voiced" and that had abolition and emancipation never occurred, the planters "must still inevitably have suffered the general ruin which engulfed them." ${ }^{\circ}$ For Ragatz, the plantation agriculture of the sugar islands was intrinsically wasteful and the planters' profits dependent on a system of monopoly trading between the colonies and the metropole. Ragatz was interested principally in the old colonies of the empire (Jamaica, Barbados, and the British Leeward Islands), settled during the seventeenth century, and he argued that from the 1760s, the planters of these islands faced competition from new British-Caribbean colonies, seized from other European powers, and from rising and more-efficient sugar producers in foreign territories. This exposed the flaws of a "fundamentally unsound order" and "a general slowing down of life, distress, and ultimate disaster relentlessly followed."

Eric Williams revisited the idea that the plantation colonies of the British Caribbean were facing an economic decline before the advent of abolitionism in his influential book of 1944, Capitalism and Slavery. ${ }^{10}$ This developed many of Ragatz's arguments into a thoroughgoing critique of British imperialist scholarship on the abolition movement and the dismantling of the British slave system. Williams proposed that the British-Caribbean sugar colonies had been lucrative and central to the eighteenth-century British empire and that the profits of the slave trade and from slave- 
produced sugar had helped to finance the British Industrial Revolution. He thereby associated the exploitation of enslaved people in the Caribbean colonies with the economic development of the mother country. Williams also equated the abolition of slavery with economic change, complicating the notion put forward by an older generation of British historians of imperialism, such as Reginald Coupland, that British abolition was the act of disinterested "saints."11

In his thesis, Williams presented the American Revolution as the pivotal moment in the planters' fall, as it finally exposed the anachronism of the old mercantile system of protected trade, under which the sugar colonies had thrived. "Far from accentuating the value of the sugar islands," argued Williams, "American independence marked the beginning of their uninterrupted decline."12 What was more, Williams held that, at the end of the eighteenth century, a new form of capitalism began to emerge, along with a new type of capitalist: industrialists, committed - in Williams's formulation - to the principle of free trade, who were happy to oppose the monopolistic privileges of the planter class. As Williams put it:

The capitalists had first encouraged West Indian slavery and then helped to destroy it. When British capitalism depended on the West Indies, they ignored slavery or defended it. When British capitalism found the West Indian monopoly a nuisance, they destroyed West Indian slavery as the first step in the destruction of West Indian monopoly. ${ }^{13}$

In this way, the fall of the planter class was firmly equated not only with the inevitability of economic decline for the slave-run plantation colonies of the British Caribbean, as Ragatz had proposed, but also with the evolution of global capitalism. The Williams thesis, on its Ragatzian foundations, saw the fall of the planters as part of agricultural cycles and economic development and served as a broadly accepted 
explanation for a generation. As Drescher notes, even historians who disagreed with Williams's argument that economic factors decided the fate of the slave system still tended to accept that the planters of the British Caribbean were presiding over a decaying sector of the imperial economy by the end of the eighteenth century. ${ }^{14}$

In his 1977 book, Econocide, Drecher presented a different interpretation. Although not the first to challenge Williams's ideas, his thoroughgoing examination of the British-Atlantic slave economy convinced many scholars to reject or rethink much of what Ragatz and Williams had proposed about the inbuilt weaknesses of the BritishCaribbean plantation complex and about the connections between capitalism, slavery and abolition. ${ }^{15}$ Drescher's careful study of trade figures from the period of the abolition debates concluded that the plantations had not been in decline at the point at which the British state elected to end the slave trade; they had, rather, been in a state of vibrant good health. Viewed both in terms of long-term secular trends (which suggested an upward movement in West-Indian production and trade) and short-term contingencies (which suggested that parliamentarians paid little or no heed to economics when they made their decision to end the slave trade), British abolition had been a case of econocide: the killing off of a healthy branch of commerce, inspired by non-economic motives. ${ }^{16}$ Rather than a simple act of pushing away an already crumbling edifice in the interests of new economic forces, the dismantling of slavery, according to Drescher, required social changes in the metropole that enabled commentators, activists, and decision makers "for the first time, to redefine a thriving trade as manstealing, and then to destroy that trade, regardless of either its economic value or its stage of development."

Following Econocide, a new perspective on the decline and fall of the British planter class took shape whereby it was not the inevitable flaws and inefficiencies of 
slavery, disruptions to trade patterns caused by the American Revolution, or the inbuilt logic of capitalism that struck down this wealthy and powerful group; instead, the rise of antislavery and the abolition of the slave trade in 1807 were the most telling blows. ${ }^{18}$ Curtailing the planters' labor supply from Africa "rigidified British slavery," denying planters the flexibility to expand and maintain production. ${ }^{19}$ The abolition of slavery, the transition to a free-labor economy, and the equalization of the sugar duties all further contributed to a decline set in process by the dawning of a new era of abolition. ${ }^{20}$ Although scholars now tend to view the rise of the abolitionists, followed by new varieties of slave resistance, as the main root causes of the planters' problems, they have, nevertheless, steered clear of a return to narratives about the saintly moral triumphs of abolitionism. In fact much recent work on abolitionist ideology and rhetoric has tended to emphasize its prescriptive visions for the reform of slave societies, visions which paid little detailed attention to the aspirations of enslaved people. ${ }^{21}$ It is also noteworthy that whilst abolitionists might not have been directly or wholly inspired by economic interests, the movement emerged from a moment of intense economic transformation and related social upheaval. Howard Temperley's comments on slavery summarize the conundrum thrown up by the timing of the rise of abolitionism and still loom large over efforts to explain it. Discussing the transatlantic slave-plantation system, Temperley noted:

precisely at a time when capitalist ideas were in the ascendant, and large-scale production of all kinds of goods was beginning, we find this system being dismantled. How could this happen unless 'capitalism' had something to do with it? If our reasoning leads to the conclusion that 'capitalism' had nothing to do with it, the chances are that there is something wrong with our reasoning. ${ }^{22}$ 
Exercised by this problem, historians have asked whether economic change fostered the rise of new groups of political activists or prompted new ways of understanding the world that might have informed antislavery, and they have presented arguments about the ways in which "class interests" and involvement in long-range global commerce shaped the rising opprobrium against slaveholding. ${ }^{23}$

More recently, however, Christopher Leslie Brown has taken a different approach, arguing that British antislavery was by no means an inevitable consequence of the broad sweep of social and economic developments or "progress" and came about rather as a result of a number of contingent factors converging in the late eighteenth century, particularly at the time of the American Revolution. The rebellion of the thirteen colonies brought debates about colonial reform and slavery to the fore in British public life and "produced an environment in which organized opposition to slavery, for the first time, could seem worthy of praise" while serving "a range of purposes at once." In this formulation, the opponents of the planters had many political interests at stake in the struggle over slavery, including the reform of imperial governance and the social and moral rejuvenation of the nation "at home" in the British Isles. ${ }^{24}$ Brown's analysis certainly advances our understanding of the rise of abolitionism and offers fresh new perspectives on the phenomenon. It also coheres with the findings of political and cultural historians who see the late eighteenth century as a moment of crisis in imperial relations and of national soul searching, when new types of British identity were forming. ${ }^{25}$

Other historians, most notably Nicholas Dirks, have begun to broaden our understanding of this turmoil, exploring how metropolitan Britons came to confront perceived "scandals of empire" by offering critiques not only of slaveholding in the West Indies but also of gratuitous examples of corruption by officials of the East India 
Company in the rapidly growing British empire in Asia. Most Britons accepted the overarching principles of an imperialism that was beginning to bestride the globe but felt distinctly queasy about particular aspects of its commerce and governance. ${ }^{26}$ Focusing on these themes encourages us to reconsider how the rise of opposition to slaveholding and the fall of the planter class relate to other aspects of change in Britain and its empire at the end of the Georgian era. They seem to suggest that opposition to slavery was linked with metropolitan efforts to legitimize and control a rapidly expanding, and apparently unbridled, British global commerce and imperialism, reforming practices that were perceived to exemplify their worst excesses and attacking groups that seemed to be particularly savage and corrupt in their pursuit of wealth and power, such as the planters. Such changes promised a more stable and manageable empire. In these ways, the debate over slavery was a hugely important strand in late eighteenth-century struggles over the future of the imperial state and British overseas trade. The slave economy might not have been inherently flawed in simple economic terms, and the campaign against it required a moral revolution, but the fall of the planters can still be seen in the context of changing imperial priorities and debates over the best future for British commercial interests.

II

The success of abolitionism and the fall of the planter class remain vital topics that can shed important light on wider issues in Atlantic and global history, and recent studies of British slaveholders have helped to improve our understanding of how planters responded to changing times at the end of the eighteenth century. New work on colonial wealth and plantation management has added weight to Drescher's contention that slavery was by no means doomed to economic failure, even in the era of abolition, 
showing that slaveholders were among the wealthiest people in the British empire and capable of technological and managerial adaptations that made production more efficient. ${ }^{27}$ Such work undermines the notion that the abolition of the slave trade and emancipation took place because of fundamental economic flaws in slavery and the plantation economy. Nevertheless, many aspects of Drescher's work remain open to question. For example, there is evidence to show that despite their innovations in production techniques and high profits during the 1790s, British-Caribbean planters were facing a financial crisis and uncertain economic prospects by the time parliament ended the slave trade, particularly those with plantations in old colonies like Jamaica. This has helped to reopen the debate about the links between economic change and the struggle for abolition. ${ }^{28}$

Efforts to understand the role of the slaveholders in the debates over slavery have also led to studies of proslavery arguments and of the transatlantic networks that bound Caribbean plantation owners to the metropole. ${ }^{29}$ Such work has helped to frame our understanding of the struggle over slavery in an Atlantic context, showing how absentee planters living in the metropole liaised with their counterparts in the Caribbean. It has also helped to reveal important gaps in our understanding of the changing character of the British-Caribbean planter class during the years leading up to emancipation, for instance by elucidating tensions between groups of planters, particularly as those connected with the more productive "new" colonies, conquered by Britain during the French Wars (notably British Guiana and Trinidad), came to supplant those from older colonies (like Jamaica and Barbados) in terms of wealth and influence.

As well as improving our understanding of the planters themselves, recent work has focused on their relations with other groups in slave society and on the new forms of opposition they faced from the 1780s onwards from within the Caribbean. Scholars 
have examined relations between planters and lowlier white colonists, many of whom also owned slaves. These poorer whites generally supported the slave system, some of them having a stronger investment in slavery than their planter neighbors, who proved more willing to compromise with the British government over the Emancipation Bill in $1833 .^{30}$ Free people of color in the colonies were a greater challenge to the status quo, and they began to organize politically against the planter class from the end of the eighteenth century. ${ }^{31}$ Planters faced serious opposition from other quarters as well. At its most extreme, resistance by enslaved people threatened to overthrow the plantation complex, but it also fed into debates about abolition and emancipation. Meanwhile, mission work by white Nonconformist preachers from the metropole served to undermine the defining principles of slavery, providing enslaved people with white allies in their conflicts with the slaveholders. ${ }^{32}$ Christianity also influenced enslaved people's own efforts to resist slavery, shaping their political consciousness and providing a new language with which to express dissent. In the transatlantic cultural contest over slavery, this posed a serious new threat to the planters because, as the historian Vincent Brown puts it, "Christianity provided a framework for a moral critique of slavery in a language that metropolitan elites were obliged to regard." 33

Recent work on the planters in the age of abolition has therefore shed new light on the difficulties they faced as their reputation declined and their political prospects worsened. It is also apparent, however, that slaves and abolitionists were up against a political force that was far from decrepit or lacking in dynamism. From the beginning of organized political campaigns against the slave trade, British slaveholders orchestrated a series of well-funded, carefully targeted campaigns against proposed reforms. These campaigns ultimately failed to stem the antislavery tide but they did influence the British government and shape public ideas about slavery and empire. The planter class 
was also a dominant social and political force in the Caribbean, able to direct the ways in which the institution of slavery was phased out. And it was still possible for planters to amass considerable fortunes during this period and to reinvest capital derived from slavery into new ventures. ${ }^{34}$

III

Rethinking the fall of the planters requires reconsideration of the challenges that diminished their power and of the ways in which those from within this group were able to shape the dismantling of the British slave system. Planters may have lost the debate over slavery, but they continued to exercise political influence and often maintained healthy incomes. As such, the articles in this volume focus both on the reversals that brought an end to the levels of wealth and power once enjoyed by British West Indian planters and on the ways in which the planter class responded to adversity, highlighting the qualified successes of factions of this group during the era of abolition.

The collection opens with Trevor Burnard's article about West Indian planters during their heyday, between the end of the seventeenth century and the American Revolution. In this period, planters became some of the richest and most influential Britons of their era. Burnard's main focus is Jamaica, the island that produced the greatest sugar fortunes of the eighteenth century. Contrary to analysis that maintains that such fortunes were a chimera, gaudy displays of wealth built on unsound and unsustainable foundations of debt and mismanagement, Burnard maintains that many West Indian fortunes were built on economically sound footings. The planters of Jamaica, in his analysis, were rational managers who knew how to make good returns on capital they borrowed and invested. This bears out many of Drescher's arguments about the profitability of slavery, its good economic prospects in the late eighteenth 
century, and the importance of the successful abolitionist campaign to planter decline. Burnard estimates that, by the time of the American Revolution, Jamaica had become as valuable to the metropole in commercial terms as a large English county; and he presents a picture of a plantation sector in good overall health at the outset of antislavery lobbying.

The immense value of the Caribbean colonies to the mother country helped to insulate British planters from political opposition for much of the eighteenth century, which meant that the intensity and popularity of abolitionist attacks against their activities came as a profound surprise to them. As Burnard notes, before the 1780s, many Britons felt uneasy about the large fortunes amassed by white West Indians but did not directly question the means by which these were acquired. Such ambivalence towards planters evaporated in the final two decades of the eighteenth century, as abolitionism gathered momentum. In the face of opposition to the Atlantic slave system, planters - along with the merchants who traded their produce and financed their activities - found new ways to organize and lobby for their commercial and political interests. The London Society of West India Planters and Merchants, directed by the London West India Committee, was the main focal point for planter political activity. It scored some successes for the so-called West India Interest, particularly during the 1790s, a decade when calls for reform were easily associated with French radicalism and when British West Indian planters were enjoying a boom in production and profits.

The turn of the nineteenth century brought bleaker political and economic prospects, particularly to those planters from older colonies such as Jamaica. The second article in this issue, by David Beck Ryden, deals with reactions to these tougher times. The Jamaican planters, representing the largest and wealthiest of the sugar colonies, were at the vanguard of the West India Interest during its failed effort to 
maintain the slave trade. Thereafter, planter lobbyists had to adapt their tactics to changed circumstances, and Ryden examines the important but overlooked period between the abolition of the slave trade in 1807 and the end of the wars with Napoleon in 1815 , noting the continued dominance of Jamaican planters within the West India Interest as well as the more subdued character of the Society's activities. He demonstrates that pro-planter lobbying scored some important successes, persuading the British government to make important concessions that benefitted planters at the expense both of British consumers and other parts of the metropolitan economy. Ministers were less amenable to the West India Interest, however, when its proposals threatened metropolitan tax revenues - as in the case of the call to use sugar to feed British livestock.

As Ryden shows, Jamaican planters suffered serious political and economic setbacks in the opening years of the nineteenth century but were not entirely defeated by the end of the slave trade and poor market conditions for their product. Other planters did better still in this period, and the third article in the issue, by Nicholas Draper, argues that some sections of the planter class enjoyed good economic prospects and increased political influence. By studying planters connected with Caribbean colonies acquired by Britain during the course of the wars with Revolutionary and Napoleonic France, Draper offers a valuable new perspective on the planter class in the nineteenth century. A "new planter class," associated with these new colonies, owned more productive plantations and reaped better profits than those associated with older colonies like Jamaica, Barbados or Antigua. Indeed, along with Brazilian and Cuban sugar, the produce of the new colonies, and especially that of British Guiana, presented planters of the older colonies with unwelcome competition. Moreover, planters with properties in the new colonies, most of who chose to live as absentee proprietors in the 
metropole, also began to play a larger role in the political activities of the West India Interest.

By 1833, planters connected to the newer British sugar colonies played a leading role in negotiations with the government over the nature of Emancipation Bill, which included several concessions to planters, including a package of financial compensation that favored those connected with Guiana and Trinidad. As Draper notes, the Jamaican presence in the London West India Committee did not entirely disappear, and it is apparent that security and social order in Jamaica - which remained Britain's most populous Caribbean colony - were key points of concern for the British government as it steered the Emancipation Bill through parliament. Nevertheless, the new colonies and capitalists with investments in them were increasingly important. These were territories with the potential for economic expansion and men receiving good returns on their investments. In this analysis, some parts of the planter class were declining faster than others during the era of abolition, and even at the point of emancipation many British planters were on the rise, with strong economic prospects and improved political influence.

Christer Petley's article is the first of two pieces that shift the focus of the volume to slaveholders in the colonies, rather than absentees in the metropole. His study looks at white West Indian social practices and the ways in which these were represented by outside commentators, including metropolitan writers and visitors to the Caribbean. Taking rituals around food and dining as its main theme, the article describes the importance of hospitality to white creole society in Jamaica. The common experience of eating and drinking together helped to cement social bonds between white men that were essential to the maintenance of white solidarity and to the continued enactment of white privilege and black subjection in a society based on slavery. 
These practices frequently drew comment from outsiders. Eighteenth-century metropolitan observers often mocked or criticized West Indian planters, but many also presented positive images of white creoles: rebuke was often balanced by sympathy. Things altered during the 1780 s, when changed ideas about both Britishness and slavery contributed to a new climate of opinion in which the planters' eccentricities were redefined as fundamental flaws of character. Their metropolitan critics not only attacked them for slaveholding but for a range of other behaviors, including sexual relationships between white men and women of color - which were commonplace in Caribbean societies - and colonial eating habits, which they saw as gluttonous and excessive. The image of white colonial slaveholders as men lacking in self control gained currency in the nineteenth century and proved difficult for planters to overturn. In various ways, metropolitan observers represented slave societies as mired in sin and corrupted by libidinous and gluttonous excess, undermining the political influence of the West India Interest and inviting imperial intervention to reform colonial societies.

The final article in the volume is by Daniel Livesay. It provides a detailed treatment of the commonplace sexual relationships between women of color and white slaveholders in the plantation colonies of the Caribbean and of their political ramifications. Ragatz, echoing some of the views of the abolitionists, saw these partnerships and resultant mixed-race children as evidence of the planters' moral decadence, another feature of a decaying socio-economic structure and nail in the coffin of planter power. Livesay, on the contrary, argues that inter-racial family groupings did not necessarily offer direct challenges to white control in eighteenth-century Jamaica. Rather, the planter elite managed these relationships by providing wealthy individuals of color with specific privileges and ensuring that some of their own mixed-race children had access to education along with relatively attractive economic prospects. 
The result was that free people of color were a fractured group within slave society: the educated and relatively wealthy colored elite, most of who had strong links to white society, were separated from the poorer majority of this group.

The age of abolition witnessed a transformation. Attitudes to inter-racial sexual relationships changed, as did Jamaican family structures. British critics railed against white-creoles' disregard for marriage, and colonists became more hesitant about mixedrace liaisons. Meanwhile, a rapid rise in the number of free people of color led to increasing instances of free-colored children with no white parent. Consequentially, inter-racial families became less accepted and less prevalent, and the result was intensified political tension between free people of color and white slaveholders. Ultimately, this was to contribute to the decline of the planter class. It was impossible for the white elite in the colonies to ignore free-colored demands for civil rights, the granting of which removed exclusive white privilege. By discussing these transformations and tensions within a colonial society, Livesay reminds us that challenges to planter power came not only from abolitionists and government ministers in the metropole, but also from within the Caribbean.

\section{IV}

The new research presented here on one diverse and changing group of planters in a specific region of the Atlantic plantation complex demonstrates that the fall of the planter class was a protracted, complicated, and contradictory phenomenon. BritishCaribbean planters were at the height of their wealth and power at the beginning of the final quarter of the eighteenth century, but from the 1780s onwards, they were forced to contend with new challenges from different quarters. By the nineteenth century, Jamaican planters, who had enjoyed such economic success during the eighteenth 
century, faced serious economic problems and were only partly successful in their efforts to lobby for governmental aid. Economically and politically, they also faced the prospect of the rise of a new group within the planter class, who owned more productive properties in territories recently seized by Britain. Simultaneously, the planters particularly those who were resident in the Caribbean - suffered from a declining public image and political challenges from within local societies. Their reputation suffered in the metropole for reasons other than simply their treatment of enslaved people and their problems in the Caribbean derived from their inability to maintain the finely weighted social and political balance that had provided the basis for their power during the eighteenth century.

Other groups benefited from the planters' discomfiture. ${ }^{35}$ In slave societies, free people of color made social and political gains at the expense of white colonists. Emancipation was an abolitionist victory that presented new opportunities for those freed from slavery. This meant that Caribbean planters did not bestride the British colonial world in the nineteenth century in the way that they had for much of the period before the American Revolution. They were forced onto the defensive in their efforts to salvage the best possible deal from the government in the face of hostile reforms; plantations went out of business; and even the most thriving sectors of the British plantation economy faced an uncertain future. However, in spite of all this, and contrary to Ragatz's analysis, the events of the 1830 s did not bring about the complete "downfall of the planter class" in the British Atlantic world or entail a decisive "end to the old order" in the Caribbean. ${ }^{36}$ Planters and plantations outlived emancipation; profits from slavery could be reinvested; and, as Williams suggested, "ideas built on these interests" could survive in the face of change "and work their old mischief.",37 


\section{Acknowledgements}

The guest editor thanks all of the speakers and other participants at the Rethinking the Fall of the Planter Class conference in September 2010 for helping to set this project in motion and Richard Follett for his time, support, and encouragement in helping to bring it to publication.

\section{Notes on contributor}

Christer Petley's work has focused on slavery and abolition in the British Caribbean, particularly on slave-owners and the planter class. He is the author of Slaveholders in Jamaica (2009) and has published articles in Slavery and Abolition, The Journal of Imperial and Commonwealth History, and The Historical Journal. He is Chair of the UK Society for Caribbean Studies and teaches History at the University of Southampton.

\section{References}

Anstey, Roger. "Capitalism and Slavery: A Critique." The Economic History Review 21, no. 2 (1968): 307-320.

Anstey, Roger. "A Re-Interpretation of the Abolition of the British Slave Trade, 18061807.” English Historical Review 87, no. 343 (1972): 304-332.

Barrett, Ian. "Cultures of Pro-Slavery: The Political Defence of the Slave Trade in Britain, c. 1787-1807.” PhD Dissertation, University of London, 2009.

Bayly, C. A. Imperial Meridian: The British Empire and the World, 1780-1830. London: Longman, 1989. 
Bender, Thomas, ed. The Antislavery Debate: Capitalism and Abolitionism as a Problem in Historical Interpretation. Berkeley: University of California Press, 1992.

Blackburn, Robin. The Overthrow of Colonial Slavery, 1776-1848. London: Verso, 1988.

Brown, Christopher Leslie. Moral Capital: Foundations of British Abolitionism. Chapel Hill: University of North Carolina Press, 2006.

Brown, Vincent. The Reaper's Garden: Death and Power in the World of Atlantic Slavery. Cambridge, MA: University of Harvard Press, 2008.

Burnard, Trevor. "“Prodigious Riches': The Wealth of Jamaica before the American Revolution.” The Economic History Review 54, no. 3 (2001): 506-24.

Burnard, Trevor. “'Passengers Only': The Extent and Significance of Absenteeism in Eighteenth-Century Jamaica.” Atlantic Studies 1, no. 2 (2004): 178-95.

Burnard, Trevor. Mastery, Tyranny, and Desire: Thomas Thistlewood and his Slaves in the Anglo-Jamaican World. Chapel Hill: University of North Carolina Press, 2004.

Burnard, Trevor. “'Rioting in Goatish Embraces': Marriage and Improvement in Early British Jamaica." The History of the Family 11, no. 4 (2006): 185-97.

Butler, Kathleen Mary. The Economics of Emancipation, 1823-1843. Chapel Hill: University of North Carolina Press, 1995.

Carrington, Selwyn H. H. The Sugar Industry and the Abolition of the Slave Trade, 1775-1810. Gainesville: University Press of Florida, 2002.

Cateau, Heather. 'The New 'Negro' Business: Hiring in the British West Indies, 17501810." In In the Shadow of the Plantation: Caribbean History and Legacy, ed. Alvin O. Thompson, 100-120. Kingston: Ian Randle Press, 2002. 
Colley, Linda. Britons: Forging the Nation, 1707-1837. London: Pimlico, 2003; first edition, 1993.

Conway, Stephen. The British Isles and the War of American Independence. Oxford: Oxford University Press, 2000.

Cooper, Frederick, Thomas C. Holt, and Rebecca J. Scott, Beyond Slavery: Explorations of Race, Labor, and Citizenship in Postemancipation Societies. Chapel Hill: University of North Carolina Press, 2000.

Cooper, Frederick and Ann Laura Stoler, eds. Tensions of Empire: Colonial Cultures in a Bourgeois World. Berkeley: University of California Press, 1997.

Coupland, Reginald. The British Anti-Slavery Movement. London: T. Butterworth, 1933.

Curtin, Philip. The Rise and Fall of the Plantation Complex: Essays in Atlantic History. Cambridge: Cambridge University Press, 1990.

da Costa, Emilia Viotti. Crowns of Glory, Tears of Blood: The Demerara Slave Rebellion of 1823. Oxford and New York: Oxford University Press, 1997.

Davis, David Brion. The Problem of Slavery in the Age of Revolution, 1770-1820. Ithaca: Cornell University Press, 1975.

Davis, David Brion. Slavery and Human Progress. Oxford: Oxford University Press, 1984.

Dirks, Nicholas B. The Scandal of Empire: India and the Creation of Imperial Britain. Cambridge, MA: Harvard University Press, 2006.

Draper, Nicholas. The Price of Emancipation: Slave-Ownership, Compensation and British Society at the End of Slavery. Cambridge: Cambridge University Press, 2010. 
Drescher, Seymour. Econocide: British Slavery in the Era of Abolition. Chapel Hill: University of North Carolina Press, 2010; first edition, 1977.

Drescher, Seymour. Capitalism and Antislavery: British Mobilization in Comparative Perspective. New York: Oxford University Press, 1986.

Drescher, Seymour. From Slavery to Freedom: Comparative Studies in the Rise and Fall of Atlantic Slavery. New York: New York University Press, 1999.

Drescher, Seymour. Abolition: A History of Slavery and Antislavery. Cambridge: Cambridge University Press, 2009.

Drescher, Seymour. Review of West Indian Slavery and British Abolition by David Beck Ryden. Slavery and Abolition 31, no. 2 (2010): 285-87.

Drescher, Seymour. The American Crucible: Slavery, Emancipation and Human Rights. London: Verso, 2011.

Eudell, Demetrius L. The Political Languages of Emancipation in the British Caribbean and the U.S. South. Chapel Hill: University of North Carolina Press, 2002.

Fergus, Claudius. “'Dread of Insurrection’: Abolitionism, Security, and Labor in Britain's West Indian Colonies, 1760-1823.” William and Mary Quarterly 66, no. 4 (2009): 757-80.

Green, William A. British Slave Emancipation: The Sugar Colonies and the Great Experiment 1830-1865. Oxford: Oxford University Press, 1976.

Greene, Jack P. "Liberty, Slavery, and the Transformation of British Identity in the Eighteenth-Century West Indies.” Slavery and Abolition 21, no. 1 (2000): 1-31. Hall, Catherine. "White Visions, Black Lives: The Free Villages of Jamaica." History Workshop Journal 36 (1993): 100-32.

Hall, Catherine. Civilising Subjects: Metropole and Colony in the English Imagination, 1830 - 1867. Cambridge: Polity, 2002. 
Heuman, Gad J. Between Black and White: Race, Politics, and the Free Coloreds in Jamaica, 1792 - 1865. Westport: Greenwood Press, 1981.

Heuman, Gad and Trevor Burnard, eds. The Routledge History of Slavery. London: Routledge, 2011.

Higman, B.W. Slave Population and Economy in Jamaica, 1807-1834. Cambridge: Cambridge University Press, 1976.

Higman, B.W. Writing West Indian Histories. London and Basingstoke, Macmillan, 1999.

Higman, B.W. Plantation Jamaica: Capital and Control in a Colonial Economy. Kingston: University of the West Indies Press, 2005.

Holt, Thomas C. The Problem of Freedom: Race, Labor, and Politics in Jamaica and Britain, 1832-1938. Baltimore: Johns Hopkins University Press, 1992.

Lambert, David. White Creole Culture, Politics and Identity during the Age of Abolition. Cambridge: Cambridge University Press, 2005.

Lambert, David. “The 'Glasgow King of Billingsgate': James MacQueen and an Atlantic Proslavery Network." Slavery and Abolition 29, no. 3 (2008): 389-413. Matthews, Gelien. Caribbean Slave Revolts and the British Abolition Movement. Baton Rouge: Louisiana State University Press, 2006.

Nechtman, Tillman W. Nabobs: Empire and Identity in Eighteenth-Century Britain. Cambridge: Cambridge University Press, 2010.

Newton, Melanie. The Children of Africa in the Colonies: Free People of Color in Barbados in the Age of Emancipation. Baton Rouge: Louisiana State University Press, 2008. 
Petley, Christer. “'Legitimacy” and Social Boundaries: Free People of Colour and the Social Order in Jamaican Slave Society.” Social History 30, no. 4 (2005): 481498.

Petley, Christer. Slaveholders in Jamaica: Colonial Society and Culture during the Era of Abolition. London: Pickering and Chatto, 2009.

Petley, Christer. “'Devoted Islands' and 'that Madman Wilberforce': British Proslavery Patriotism during the Age of Abolition." Journal of Imperial and Commonwealth History 39, no. 3 (2011): 393-495.

Ragatz, Lowell Joseph. The Fall of the Planter Class in the British Caribbean, $1763-$ 1833. New York: Octagon, 1963; first edition, 1928.

Rugemer, Edward Bartlett. The Problem of Emancipation: The Caribbean Roots of the American Civil War. Baton Rouge: Louisiana State University Press, 2009.

Ryden, David Beck. “'One of the Fertilest Pleasentest Spotts': An Analysis of the Slave Economy in Jamaica’s St Andrew Parish, 1753.” Slavery and Abolition 21, no. 1 (2000): 32-55.

Ryden, David Beck. "Does Decline Make Sense? The West Indian Economy and the Abolition of the British Slave Trade.” Journal of Interdisciplinary History 31, no. 3 (2001): 347-74.

Ryden, David Beck. West Indian Slavery and British Abolition, 1783-1807. Cambridge: Cambridge University Press, 2009.

Satchell, Veront. “Technology and Productivity Change in the Jamaican Sugar Industry, 1760 - 1830.” PhD Dissertation, University of the West Indies (Mona), 1993.

Sheller, Mimi. Democracy After Slavery: Black Publics and Peasant Radicalism in Haiti and Jamaica. Gainsborough: University of Florida Press, 2000. 
Stedman, John. Narrative of a Five Year's Expedition against the Revolted Negroes of Surinam, 2 vols. London: J. Johnson and J. Edwards, 1796.

Swaminathan, Srividhya. Debating the Slave Trade: Rhetoric of British National Identity. London: Ashgate, 2009.

Temperley, Howard. “Capitalism, Slavery, and Ideology.” Past and Present 75 (1977): $94-118$.

Thurston, Thomas. "Slavery: Annual Bibliographical Supplement (2009)." Slavery and Abolition 31, no. 4 (2010): 565-637.

Turner, Mary. Slaves and Missionaries: The Disintegration of Jamaican Slave Society, 1787-1833. Urbana: University of Illinois Press, 1982.

Wahrman, Dror. The Making of the Modern Self: Identity and Culture in EighteenthCentury England. New Haven and London: Yale University Press, 2004.

Ward, J.R. British West Indian Slavery, 1750-1834: The Process of Amelioration. Oxford: Oxford University Press, 1988.

Williams, Eric. Capitalism and Slavery. London: Andre Deutsch, 1964; first edition, 1944.

\section{Notes}

${ }^{1}$ Curtin, The Rise and Fall of the Plantation Complex.

${ }^{2}$ For essays providing overviews of the rise and fall of Atlantic slavery, see Heuman and Burnard, The Routledge History of Slavery; and for recent synoptic interpretations of these processes, see Drescher, Abolition and Blackburn, The American Crucible. The literature on Atlantic slavery and its abolition is now vast and continues to expand. The journal Slavery and Abolition publishes an annual bibliographic supplement to help scholars navigate the field. See Thurston, "Slavery: Annual Bibliographical Supplement." 
${ }^{3}$ Studies providing overviews of these events include Green, British Slave

Emancipation; Davis, The Problem of Slavery in the Age of Revolution; Davis, Slavery and Human Progress; Blackburn, The Overthrow of Colonial Slavery, 419-72.

${ }^{4}$ See Drescher, From Slavery to Freedom; Cooper, Holt and Scott, Beyond Slavery; Rugemer, The Problem of Emancipation.

${ }^{5}$ Drescher, Econocide, 7.

${ }^{6}$ Patrick Bryan, quoted in Higman, Writing West Indian Histories, 167.

${ }^{7}$ Higman, Writing West Indian Histories, 167.

${ }^{8}$ Ragatz, Fall of the Planter Class, vii.

${ }^{9}$ Ragatz, Fall of the Planter Class, viii.

${ }^{10}$ Williams, Capitalism and Slavery.

${ }^{11}$ Coupland, The British Anti-Slavery Movement.

${ }^{12}$ Williams, Capitalism and Slavery, 120.

${ }^{13}$ Williams, Capitalism and Slavery, 169.

${ }^{14}$ Drescher, Econocide, 5-7.

${ }^{15}$ Roger Anstey offered diligently researched critiques of Williams's assertion that economic interests had been important to parliamentary debates about the slave trade. See Anstey, "Capitalism and Slavery: A Critique"; Anstey, "A Re-Interpretation of the Abolition of the British Slave Trade."

${ }^{16}$ Drescher, Econocide.

${ }^{17}$ Drescher, Econocide, 186.

${ }^{18}$ Not all scholars have adhered to Drescher's arguments and some have steadfastly rejected them. See in particular, Carrington, The Sugar Industry and the Abolition of the Slave Trade.

${ }^{19}$ Drescher, Econocide, 148.

${ }^{20}$ In his 1976 study of the Jamaican slave economy after 1807, B.W. Higman anticipated some of Drescher's arguments about the negative effects of abolition on Caribbean economic output. Higman, Slave Population and Economy. See also Ward, British West Indian Slavery.

${ }^{21}$ For examples, see Eudell, The Political Languages of Emancipation; Hall, Civilising Subjects; Hall, 'White Visions, Black Lives'.

22 Temperley, "Capitalism, Slavery, and Ideology,” 105.

${ }^{23}$ See Bender, The Antislavery Debate; Drescher, Capitalism and Antislavery.

${ }^{24}$ Brown, Moral Capital, 458, 461-2. 
${ }^{25}$ See for examples, Colley, Britons, especially 350-60; Bayly, Imperial Meridian;

Conway, The British Isles and the War of American Independence; Wahrman, The Making of the Modern Self.

${ }^{26}$ Dirks, The Scandal of Empire, especially 32-34. See also Nechtman, Nabobs.

${ }^{27}$ See Burnard, "Prodigious Riches"; Ryden, "One of the Fertilest Pleasentest Spotts";

Ryden, West Indian Slavery; Higman, Plantation Jamaica; Satchell, “Technology and

Productivity Change"; Cateau, “The new 'Negro' Business.”.

${ }^{28}$ See Ryden, "Does Decline Make Sense”; Ryden, West Indian Slavery; Drescher, Review of West Indian Slavery.

${ }^{29}$ See Greene, "Liberty, Slavery, and the Transformation of British Identity"; Lambert, White Creole Culture; Lambert, "The 'Glasgow King of Billingsgate"”; Ryden, West Indian Slavery, especially 40-82; Barrett, "Cultures of Pro-Slavery”; Swaminathan, Debating the Slave Trade; Draper, The Price of Emancipation, especially 75-113; Petley, "Devoted Islands."

${ }^{30}$ On white society in eighteenth century Jamaica, see Burnard, Mastery, Tyranny, and Desiere. On the nineteenth century, see Petley, Slaveholders in Jamaica; Lambert, White Creole Culture, especially 73-104.

${ }^{31}$ For the most detailed recent work on free people of color in a British Caribbean context, see Newton, The Children of Africa in the Colonies. See also Heuman, Between Black and White; Petley, "'Legitimacy' and Social Boundaries"; Burnard, "Rioting in Goatish Embraces."

${ }^{32}$ Fergus, 'Dread of Insurrection'; Matthews, Caribbean Slave Revolts. For recent work on missionaries, see Hall, Civilising Subjects. On missionaries and antislavery protests by slaves, see also da Costa, Crowns of Glory, Tears of Blood; Turner, Slaves and Missionaries.

${ }^{33}$ Brown, The Reaper's Garden, 229.

${ }^{34}$ On the resilience of planter power and wealth, see Holt, The Problem of Freedom; Sheller, Democracy After Slavery; Butler, The Economics of Emancipation; Draper, The Price of Emancipation, 270-78.

${ }^{35}$ As Higman puts it: "Good times, bad times, can be one and the same, depending on one's location in the firmament." Higman, Writing West Indian Histories, 165.

${ }^{36}$ The quotes are from Ragatz, Fall of the Planter Class, 457.

${ }^{37}$ Williams, Capitalism and Slavery, 211. 